\title{
The Dinas Silica Brick
}

\author{
Michael J. Owen
}

Received: 23 October 2013 / Accepted: 26 February 2014 / Published online: 3 April 2014

(C) Springer Science+Business Media Dordrecht 2014

Given that oxygen and silicon are the two most common elements in the Earth's crust, one can never be very far from silicate minerals in one form or other, typically feldspar or quartz. However, there are places where one feels particularly close to pure silica and one of these is the area around the Dinas Rock near Glyn Neath in my homeland of South Wales. This rock has given its name to a particular kind of silica refractory brick, the Dinas brick, that is still available worldwide (for example, the Xiamen Elisa Bags company in China and the Mirell Group in Yekaterinburg, Russia) although the companies near the Dinas Rock that gave the bricks their name no longer exist. They were central to the refining of pure metals from the start of the Industrial Revolution. They quarried the particularly pure silica sand from mines and quarries close to the Dinas Rock from which they manufactured refractory bricks destined for use in industrial furnaces all over the world. The industry began to close down in the early $20^{\text {th }}$ century and all of the facilities were closed and abandoned after the end of the $2^{\text {nd }}$ world war. So significant were the silica bricks exported from South Wales during the Industrial Revolution that the word Dinas entered into other languages, most notably Russian, to mean any refractory brick.

Paradoxically, the Dinas Rock (Welsh: Graig y Ddinas, "Fortress Rock" or "City Rock") is not siliceous at all; it is a carboniferous limestone promontory that derives its name from the Iron Age earthworks on its summit. Despite the

M. J. Owen $(\bowtie)$

Michigan Molecular Institute, 1910 West Saint Andrews Road, Midland, MI 48640-2696, USA

e-mail: michaelowen01@ chartermi.net mining heritage, the area is still a beautiful one to visit attracting nature buffs, walkers, hikers, climbers, cavers and the like. It lies within the Brecon Beacons National Park and the Fforest Fawr Geopark and is owned by the Forestry Commission. Much of the old silica mines are now flooded and should be entered only by skilled cave divers. Annette Price, an experienced caver and professional photographer, recently had some remarkable photographs taken inside the flooded Dinas silica mine featured in several UK newspapers. Prints can be purchased through her website www. h2ophhotography.co.uk. One of her photographs, Fig. 1, is reprinted here with her permission.

According to The British Clayworker (Vol. 16, p. 248, Dec. 1907), the term Dinas Brick was apparently first employed by Young in 1822 to describe bricks manufactured by him from Dinas sandstone in the Vale of Neath in Wales. Their composition then was $95 \%$ silica, $4 \%$ clayey matter, and $1 \%$ fluxing oxides. One of the most striking differences between Dinas and ordinary fire-bricks is their expansion when heated, whilst ordinary fire-bricks contract. The Online Encyclopedia defines Dinas Brick as an infusible kind of brick made of a peculiar rock containing $98 \%$ of silica with a little alumina which occurs at Dinas, in the Vale of Neath in South Wales. The rock is crushed, moistened, and molded by machine. Such machines are still available today, primarily from China.

The Fforest Fawr Geopark time-line informs us that the Young referred to in the previous paragraph, better known as William Weston Young, invented the refractory brick in 1820 and founded the Dinas Silica Brick Company in 1822. The process of vitrifying the walls of a ceramic brickbuilt furnace had been invented earlier but Young's solution was to build the entire furnace from his silica bricks. His 


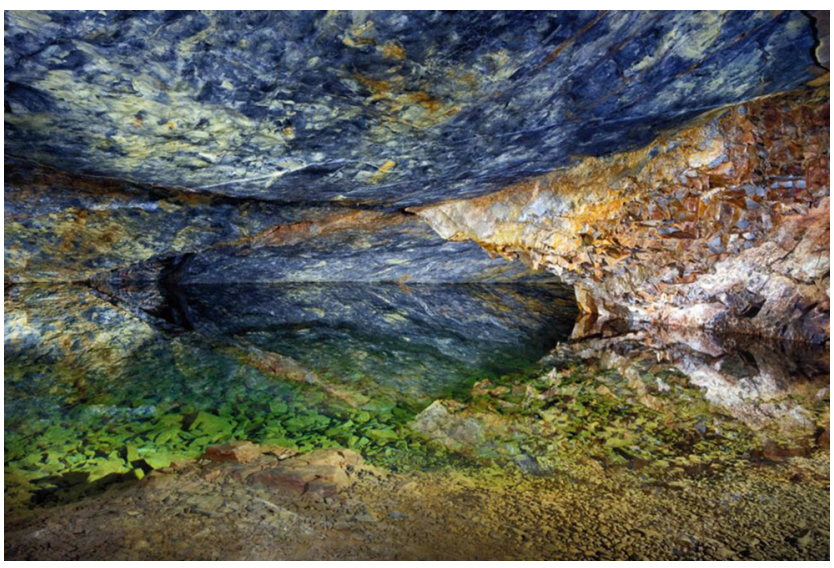

Fig. 1 Inside the flooded Dinas Silica Mine, with kind permission of Annette Price

approach was more durable and ultimately more economical than the earlier technique. British patent No. 5047 apparently covers this invention but verification has not been possible as there is no online search available for patents prior to 1890 . As the industry developed, several mines, quarries and brick manufactories arose in the region. Figure 2 is an old advertisement for one of these companies which closed in the late 1930s. Penwyllt, now a caving center much reduced from its industrial heyday, lies about seven miles NW of the Dinas Rock in a direct line.

From the city of Bristol in England, Young definitely fell under the spell of this picturesque part of Wales. He is the author of the greatly admired "Guide to the Beauties of Glyn Neath (1835)" and the man who first recorded the popular names of the waterfalls that grace this lovely region. Original copies of the book are extremely rare. A limited edition of 1500 was republished in 1974 (your correspondent owns number 1316) and the book is now freely available as a Historical Print Edition (2011) from the British Library [ISBN -10-1241311358].

Fig. 2 Advertisment for the Penwyllt Dinas Silica Brick Company

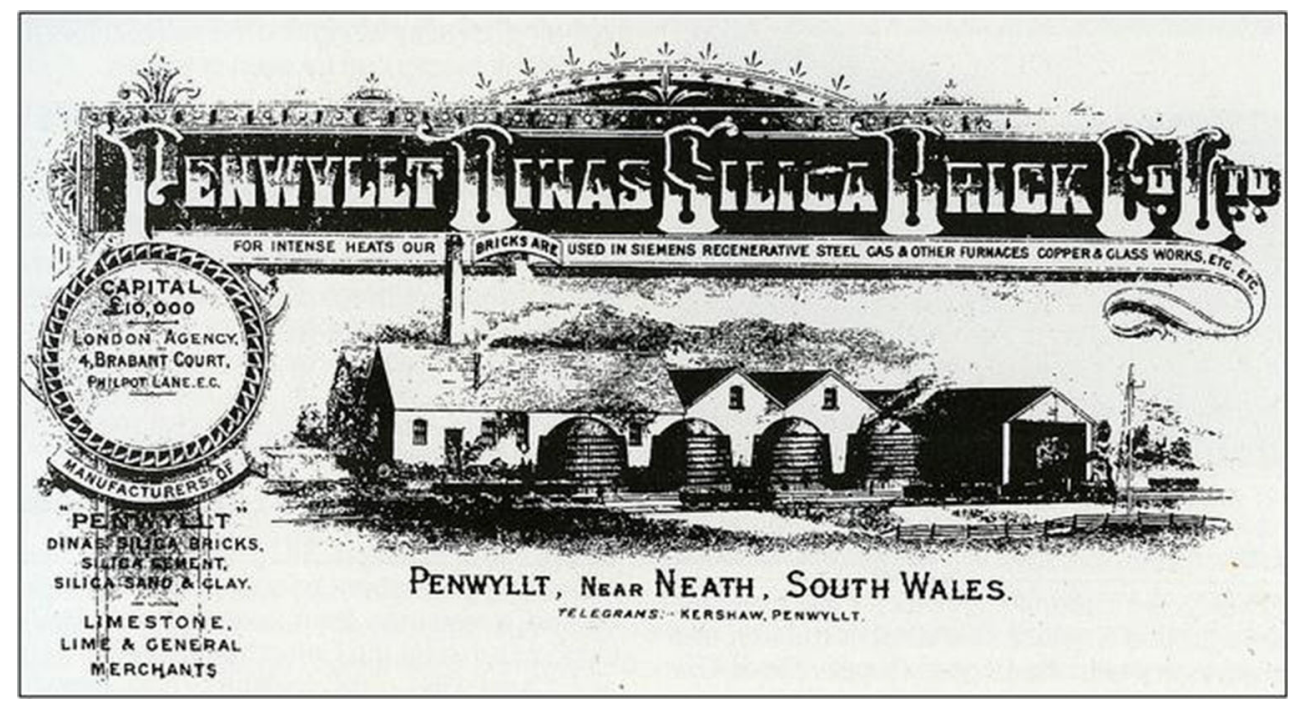

